\title{
Assessing sustainability factors of farmer seed production: a case of the Good Seed Initiative project in Tanzania
}

\author{
M. K. Kansiime ${ }^{1 *}$ D, M. Bundi ${ }^{1}$, J. Nicodemus², J. Ochieng ${ }^{3}$, D. Marandu ${ }^{4}$, S. S. Njau ${ }^{4}$, R. F. Kessy ${ }^{5}$, F. Williams ${ }^{1}$, \\ D. Karanja', J. A. Tambo ${ }^{6}$ and D. Romney ${ }^{1}$
}

\begin{abstract}
Background: Quality seed is at the core of the technological packages needed to increase crop production, nutrition, and rural wellbeing. However, smallholder farmers in Tanzania have limited access to affordable quality seeds, and over $90 \%$ of seed sown is saved by farmers from previous harvests, though its quality is often poor. The Good Seed Initiative (GSI) aimed to enhance access to quality African indigenous vegetable (AIV) seed in Tanzania, through the promotion of farmer seed production, using two models_contract farming and Quality Declared Seed (QDS). This study assessed post-GSI project sustainability factors and explored the prospects for replicating the approach in a wider regional context.
\end{abstract}

Methods: The study was conducted in Arusha and Dodoma, targeting locations where the GSI project was implemented. Qualitative tools employing focus group discussions (73 men, 69 women), and key informant interviews were used for data collection.

Results: Farmer seed production under both models continued to thrive, creating avenues for income diversification and contributing over $50 \%$ to household incomes. Farmer seed production contributed to increased availability of quality seed for vegetable growers, especially in central Tanzania that is less served by the formal sector. However, QDS production was challenged by a lack of access to foundation seed, inspections, and seed testing services, which are key for quality seed production.

Conclusions: Results reveal unequivocally that farmer seed production offers a potentially sustainable solution to the problem of seed supply while providing income benefits for seed producers. The market-based approach used by the project and partnerships with the formal sector, coupled with stimulation of demand through nutritional awareness campaigns, were strong contributory factors to the survival of farmer seed production. Farmer-led seed systems, especially QDS, deserve support from the government to develop a tailored and appropriate seed system that meets the ever-evolving needs of smallholder farmers. Adoption gender-inclusive approaches, particularly in contract farming is paramount to benefit women as much as men.

Keywords: African indigenous vegetables, Contract farming, Gender, Quality declared seed, Seed regulation

\section{Background}

Quality seed is at the core of the technological packages

\footnotetext{
*Correspondence: monkansiime@yahoo.co.uk; m.kansiime@cabi.org

${ }^{1}$ CABI Africa, P.O. Box 633-00621, Nairobi, Kenya

Full list of author information is available at the end of the article
}

needed to increase crop production, nutrition, and rural wellbeing $[3,4,26,36]$, and an entry point for achieving multiple development goals [29]. Seed availability and quality are the two key issues that farmers are concerned with for the success of the crop [6]. In Tanzania, quality seed is generally supplied by public seed enterprises and 
private seed producers, however, they mainly concentrate on a few cereal crops, particularly hybrid maize in northern parts of Tanzania and in the Southern Highlands where commercial agriculture is most prevalent, which comes at the expense of developing a strong presence in the country's central and western regions [16]. Despite the strong focus, estimates of the market share for improved maize is about 10\% [47]. For all other crops, including some that are a priority for food security and nutrition such as grain legumes, vegetables, millets, cassava, and sweet potatoes, the share is considerably lower, and farmers rely on informal sources for their seed [7, 46]. These crops are considered less profitable to seed companies because of uncertain and fluctuating demand caused by competition from farm-saved seed, high transportation and storage difficulties (e.g. root crops), and strong regionally specific preferences (e.g. indigenous vegetables) [14]. The problem is that much of this informal seed is often poor [26], leading to persistent low yields and food insecurity [31].

African indigenous vegetables (AIVs) are rich in micronutrients and other health-promoting phytochemicals; nutrient-dense vegetables complement staple-based diets, providing both food and nutrition security [19, 34, 39], as well as contributing to livelihoods of supply chain actors $[10,15,45]$. In recent years, the demand for AIVs in Tanzania and other East Africa countries has increased, but limited availability and accessibility of quality seeds of preferred varieties is a key constraint to the ability of farmers to deliver improved produce to consumers [2, 13, 43]. Weinberger and Msuya [44] estimated that the share of Africa indigenous vegetables (AIVs) seeds sold by the formal sector in Tanzania is small, and no more than $10 \%$ of their total seed sales. As such, most vegetable producers are seed-insecure [28].

Between 2013 and 2016, CABI's Good Seed Initiative (GSI) worked with partners in Tanzania to strengthen the seed system for AIVs through the promotion of farmer seed production. Farmer seed production is a system where farmers have direct control over seed selection, production, quality, and distribution [6, 22]. Strengthening farmer seed systems, therefore, increases seed security and ensures variety diversification $[6,12,14]$, while simultaneously contributing to the sustainability of farmers' livelihood [1, 25, 38, 40]. An outcome evaluation of the GSI project indicated increased farmer incomes for seed producers, increased dietary diversity for project participants, and institutional-level working improvements (better market linkages, seed system policy development) $[1,24,33]$. While the GSI project was able to achieve its targets, documentation of the sustainability of the initiative is an essential element to guide policy and practice in seed system development.
Based on the above analysis, the present study aimed to assess post-GSI project sustainability factors and explore the prospects for replicating the approach in a wider regional context. Seed system sustainability relies on the proper functioning of three key processes: (i) production and distribution of quality seed; (ii) innovation for enhanced productivity, resilience and product quality; (iii) regulation to ensure quality and varietal identity of seeds circulating in the system [42], and its ability to continue to deliver benefits to seed producers and the wider community [18].

\section{Methods}

\section{Description of intervention and study area}

The Good Seed Initiative (GSI) worked with AIV seed sector stakeholders in Tanzania to strengthen the seed system for AIVs through the promotion of farmer seed production. This was aimed at increasing access to quality seed while increasing incomes and food security of smallholders engaged in vegetable value chains. The project was implemented between 2013 and 2016 in the north (Arusha) and central (Dodoma). According to HODECT [21], the northern highlands zone represents the highest potential for diverse horticulture investments, while the central zone is emerging as a production area for horticultural crops for the local and regional markets. The two zones also present a contrast in terms of seed markets, with the northern zone having more seed companies and a fairly well-developed seed market compared to the central.

Farmer seed production was organized under two distinct systems: certified seed production through farmer contracts (out-grower scheme) with commercial seed companies in the north, and Quality Declared Seed (QDS) production in the central zone. A market-based approach was used where seed producers were provided information on business development services, marketing and market intelligence, contract negotiation, the establishment of seed demand, identification of seed traders and markets, and establishment of business contracts. Multi-stakeholder innovation platforms (one in Arusha and one in Dodoma) were established to discuss bottlenecks along the value chain and find joint solutions, and link seed producers to seed buyers. Awareness campaigns-focusing on the health and nutritional benefits of AIVs, preparation and cooking techniques, postharvest processing, and value addition-were also held to enhance the consumption of vegetables to stimulate local demand for AIVs and therefore for quality AIV seed. Twenty farmer groups were engaged during the project; half of whom were trained in both seed and vegetable production, while the other half were trained in vegetable production only. 


\section{Data collection}

Data were collected in August 2019 (3 years after GSI project closure) from Arumeru district (Arusha), and Kongwa and Mpwapwa districts (Dodoma), targeting communities where farmers were trained in both seed and vegetable production to get perspectives of both seed producers and seed consumers (vegetable growers). Qualitative approaches employing focus group discussions (FGDs) and key informant interviews were used for data collection. These approaches have been used in seed system assessments $[5,8,17,30]$.

Focus group discussions were held in seven communities and included both those who had participated in the farmer training during the project and those who did not, but reside within the community. A total of 142 farmers (73 men and 69 women) participated in the discussions (Table 1). The age of FGD participants ranged from 19 to $>50$ years, and the FGDs were mostly represented by people aged between 36 and 60 years. Village chiefs, community leaders, and extension personnel were contacted to help with organizing the focus groups. Each focus group took between $1 \mathrm{~h}$ and $1.5 \mathrm{~h}$, and the discussions were conducted in Kiswahili, the national language of Tanzania. Consent was obtained from participants before the interviews. While the standard number of participants for an FGD is 12, in some cases more farmers turned up than anticipated. In such cases, the Research team held general discussions with the entire group, and later smaller groups were made particularly with women and youth (who were mostly fewer in large groups) to obtain their perspectives as well.

Core questions in each FGD included aspects on AIV production, marketing, and consumption; access to AIV seed and quality rating of the seed; farmer seed production knowledge and trends; achievements from seed production for households and at the community level; and access to institutional services (e.g. extension, credit, and quality assurance) for seed production. Responses from focus groups were validated through key informant interviews, which included agro-dealers, seed companies, Tanzania Official Seed Certification Institute (TOSCI), Agricultural Seed Agency (ASA), and extension personnel in Dodoma and Arusha.

\section{Data analysis}

Data from all the FGDs and key informants were entered into MS Excel. Qualitative content analysis was used for data analysis. This method has been used for the interpretation of contextual data by using a systematic classification process that involves coding to identify patterns or themes across the respondent groups. Patterns of responses were then summarized into key themes (Table 2). Data presentation was also illustrated by recounting relevant experiences by smallholder farmers participating in the focus group discussions.

\section{Results}

Seed system functioning

Farmer seed production and distribution

Farmer seed production continued after the GSI project closure with farmers mainly producing seed for African eggplant (Solanum aethiopicum), Amaranth (Amaranthus spp.), African nightshade (Solanum scabrum), Ethiopian mustard (Brassica carinata), and Okra (Abelmoschus esculentus). The number of seed producers and quantities of seed produced increased attributed to the income potential of AIV seed production. For example, in 2019, 45 farmers in the three study villages in Arusha had AIV seed production contracts, compared to about 10 in 2016 in the same villages. Six seed companies (East Africa Seed Company, Beula Seed, East-West Seed Company, Alpha Seed Company, AfricAsia Seed Company, and Kibo Seed Company) contracted seed producers in 2019 compared to only three companies

Table 1 Farmer groups involved in the FGD by location and number of participants

\begin{tabular}{|c|c|c|c|c|c|c|c|c|}
\hline \multirow[t]{2}{*}{ District } & \multirow[t]{2}{*}{ Village } & \multirow[t]{2}{*}{$\mathbf{N}$} & \multirow[t]{2}{*}{ Seed growers ${ }^{a}$} & \multicolumn{2}{|c|}{ Gender } & \multicolumn{3}{|c|}{ No. per age group in years } \\
\hline & & & & Male & Female & $<35$ years & $36-60$ years & $>60$ years \\
\hline Arumeru & Kikwe & 23 & 6 & 8 & 15 & 8 & 13 & 2 \\
\hline Arumeru & Maweni, & 13 & 4 & 9 & 4 & 4 & 7 & 2 \\
\hline Arumeru & Karangai & 10 & 3 & 8 & 2 & 4 & 6 & 0 \\
\hline Mpwapwa & Tambi & 22 & 22 & 5 & 17 & 8 & 12 & 2 \\
\hline Mpwapwa & Mbori & 20 & 2 & 2 & 18 & 8 & 10 & 2 \\
\hline Kongwa & Nghumbi & 34 & 14 & 28 & 6 & 10 & 21 & 3 \\
\hline \multirow[t]{2}{*}{ Kongwa } & Tubugwe & 20 & 7 & 13 & 7 & 2 & 14 & 4 \\
\hline & & 142 & 58 & 73 & 69 & 44 & 83 & 15 \\
\hline
\end{tabular}

a Participants in the FGDs who were growing seed at the time of the study 
Table 2 Themes and categories by farmer seed production model

\begin{tabular}{|c|c|c|}
\hline \multirow[t]{2}{*}{ Theme } & \multicolumn{2}{|l|}{ Response categories } \\
\hline & Contract farmers (Arusha) & QDS farmers (Dodoma) \\
\hline Seed production & $\begin{array}{l}\text { Knowledge and skills } \\
\text { Seed processing equipment } \\
\text { Pests and disease management } \\
\text { Embedded financial and technical services }\end{array}$ & $\begin{array}{l}\text { Knowledge and skills } \\
\text { Pests and disease management } \\
\text { Access to technical and financial services } \\
\text { Access to foundation seed }\end{array}$ \\
\hline Seed marketing & $\begin{array}{l}\text { Seed sold through contracts with seed companies } \\
\text { Limited women participation in contract seed production }\end{array}$ & $\begin{array}{l}\text { Fragmented QDS markets } \\
\text { Linkages between farmers and agro-dealers } \\
\text { Lack of seed differentiation by buyers } \\
\text { Seed packaging and traceability }\end{array}$ \\
\hline Seed access & $\begin{array}{l}\text { Own seed production } \\
\text { More seed growers }\end{array}$ & $\begin{array}{l}\text { Own seed production } \\
\text { Seed sold locally } \\
\text { Increased seed demand }\end{array}$ \\
\hline \multirow[t]{2}{*}{ Household welfare } & $\begin{array}{l}\text { Additional income source } \\
\text { Better quality of life }\end{array}$ & $\begin{array}{l}\text { Additional income source } \\
\text { Better quality of life }\end{array}$ \\
\hline & Nutritional awareness & Nutritional awareness \\
\hline Seed regulation & Seed testing by seed companies & Adherence to QDS standards \\
\hline
\end{tabular}

in 2016. Interviews with two of the seed companies (EA Seed and AfricAsia) confirmed an increase in the quantity of farmer contracted seed in the region (Arusha and Manyara), and interest by other seed companies to work with farmers for seed bulking. The two companies had increased their seed contracts from 14 MT (2016) to 41 MT (2019) for AIVs and other vegetables and contracted farmers increased from 112 to 250 in the same period. The crop range also increased to include globally important vegetables such as tomato (Solanum lycopersicum), pepper (Capsicum annuum), cucumber (Cucumis sativus), watermelon (Citrullus lanatus), and onions (Allium cepa), owing to better knowledge and skills in seed production displayed by farmers. The number of farmers growing QDS also increased in the study locations, following an increase in demand for seed within the district and Dodoma generally. For example, in Mbori village in Mpwapwa district, only two farmers were trained during the GSI project in seed production, but up to 80 farmers were producing seed at the time of the study.

Seed distribution in the north was straightforward since seed companies bought all the contracted seed at an agreed price, providing guaranteed markets. In the central, QDS growers mainly sold their seed to vegetable producers within the community, and agro-dealers and seed merchants who sourced the seed directly from the communities where it was produced. Seed merchants and agro-dealers bought, on average, $150 \mathrm{~kg}$ of seed, and one agro-dealer bought up to 5 tons of amaranth seed from farmers in 2018. Seed sales within communities were mainly in small quantities (20-100 g). Though they generally sold most of the seed, QDS producers indicated that the market was fragmented and not consistent.

\section{Seed system innovations and strategic linkages}

There were noted differences in access to services and inputs necessary for quality seed production between QDS and contract farmers. Seed producers under contract continued to access extension, quality assurance, and seed testing services, provided by contracting seed companies. Seed companies also provided inputs (foundation seed, fertiliser, pest control products), as well as cash advances to facilitate critical production activities such as seeding, harvesting, seed processing, and transportation. Cash advances ranged between Tanzania shillings (TZS) 71,000 and TZS 120,000 per ha (approx. US\$ 33-57). Producers for QDS on the other hand did not receive much technical support from the extension after the project end, and access to finance was only possible through the informal financial sector. Although there was an increase in the number of farmers entering seed production, the new farmers relied on farmer-to-farmer knowledge sharing, which may cast doubts about the acquired skills. Producers also lacked access to foundation seed, and seed inspections and seed quality testing had ceased to take place, so produced seed was not true QDS. Indeed, this study identified knowledge gaps from discussions with farmers, in particular on quality seed standards, relevant agronomic practices, seed storage, field monitoring, pest and disease management, and appropriate use of chemicals.

\section{Seed regulation}

Farmer seed production is embedded in the Seeds Act 2003 and Seed Regulation 2007. Farmers can produce certified seed under supervision and contract by seed companies and the contracting seed company is responsible 
for ensuring quality assurance. Farmers can also produce QDS supervised by TOSCI or its representative at the district level. Initially, QDS sales were restricted to an administrative ward but, by helping to demonstrate the high quality of seed produced under QDS regulations, the GSI project contributed to advocacy initiatives by the Integrated Seed Sector Development (ISSD) and others. The Seeds (Amendment) Regulations 2017 allowed QDS sales to take place across all wards within a district (URT, 2017), which opened up more market opportunities for registered and trained QDS seed producers.

\section{Benefits of farmer seed production} Increased availability of quality AIV seed

Seed companies and agro-dealers indicated that farmer seed production contributed to an increase in the availability of quality AIV seed. The quality of farmer-produced seed had consistently improved, owing to increased experience in seed production, processing, and handling. In particular, seed companies confirmed that seed obtained from seed producers had better germination rates, was true to type, and clean. As a result, the rejection rate by seed companies had reduced from about 20\%, 3-4 years ago, to less than $5 \%$ in 2019 . Vegetable growers also reported increased availability of quality seed which enhanced seed access for seasonal planting, especially in Dodoma where seed production was under QDS.

To understand differences in the two seed production systems, FGD participants were asked to rate the changes in quality and availability of AIV seed between 2016 and 2019 (see Table 3). The rating was based on a three-point scale; 'agree, 'don't agree', or 'not sure'. The final ratings were based on a majority decision or consensus during FGDs. In Arusha, seed users 'agreed' with most of the statements, except those relating to seed affordability, sufficiency, farmers' ability to produce seed, and seed availability during critical sowing periods. Since seed production in this zone was under contract, all seed was sold to contracting seed companies, and seed sales within the community were minimal, occurring only when seed producers had excess production (above contracted quantities). Without the ability to buy from local seed producers directly, vegetable growers continued to source seed from agro-dealers at prevailing market prices, which were comparable to 2016.

In Dodoma, seed users 'agreed' with all the statements about seed availability, accessibility, affordability, and sufficiency, which they indicated was better compared to 2016. Seed users stated that there was an increase in the number of local seed producers which led to greater seed availability and favourable prices compared to 2016 . The seed users also indicated that they had gained knowledge on the value of quality seed, seed quality attributes, and seed selection through farmer-to-farmer learning, which had also helped them to produce seed for their own consumption instead of relying on markets. Seed users rated the quality of farmer-produced seed as good, but seed producers disagreed (especially in Ngh'umbi and Tubugwe villages in Kongwa district), citing seed recycling due to a lack of foundation seed.

\section{Increased production and consumption of AIVs}

The majority (75\%) of households in the study areas grew AIVs both for sale and home consumption. Amaranths, African nightshade, and African eggplant were ranked as the most important AIVs, grown mainly for sale. Pumpkin leaves (Cucurbita maxima), cowpea leaves (Vigna unguiculata), and sweet potato leaves (Ipomoea batatas) on the other hand were primarily grown for home consumption, and often in intercrop with the key staple maize, thus occupied relatively bigger acreage compared to other AIVs grown by households.

Farmers reported an increase in quantity of AIVs produced as well as the number of households entering into AIV production since 2016, particularly men and youth. This was occasioned by increased access to better quality seed within the community, better farmer knowledge and skills on AIV production, and income potential of AIVs. Similarly, respondents reported an increase in household consumption of AIVs and diet diversification contributing to better household nutrition, attributed to increased awareness and attitude change as vegetables were no longer considered a 'poor man's food' or 'fodder for livestock', a highly held misconception in the past. Respondents affirmed this by reporting an increased emergence of specialty restaurants (especially in Arusha) that serve AIVs to their clientele; and farmers in Kongwa district indicated that they sold amaranth to Dar es Salaam, more than $200 \mathrm{~km}$ away, and indication of the increased market demand for AIVs.

\section{Improved livelihoods and social status in the community}

Both seed production models created an avenue for income diversification and substantially contributed to household incomes. For example, the average earnings from Amaranth seed production in Dodoma were estimated at TZS 1,800,000 (approx. US\$ 857) per ha per season which surpassed income from production of traditional crops such as maize, sorghum and sunflower which was estimated at TZS 420,000 (approx. US\$ 200) per ha per season by focus group discussion participants. In comparison to traditional crops, AIV seed fetched a higher value per unit, and the crops' early maturity provided a regular income because farmers were able to plant several crops per growing year (2-3 times a year) compared to key staples that were grown only once a 


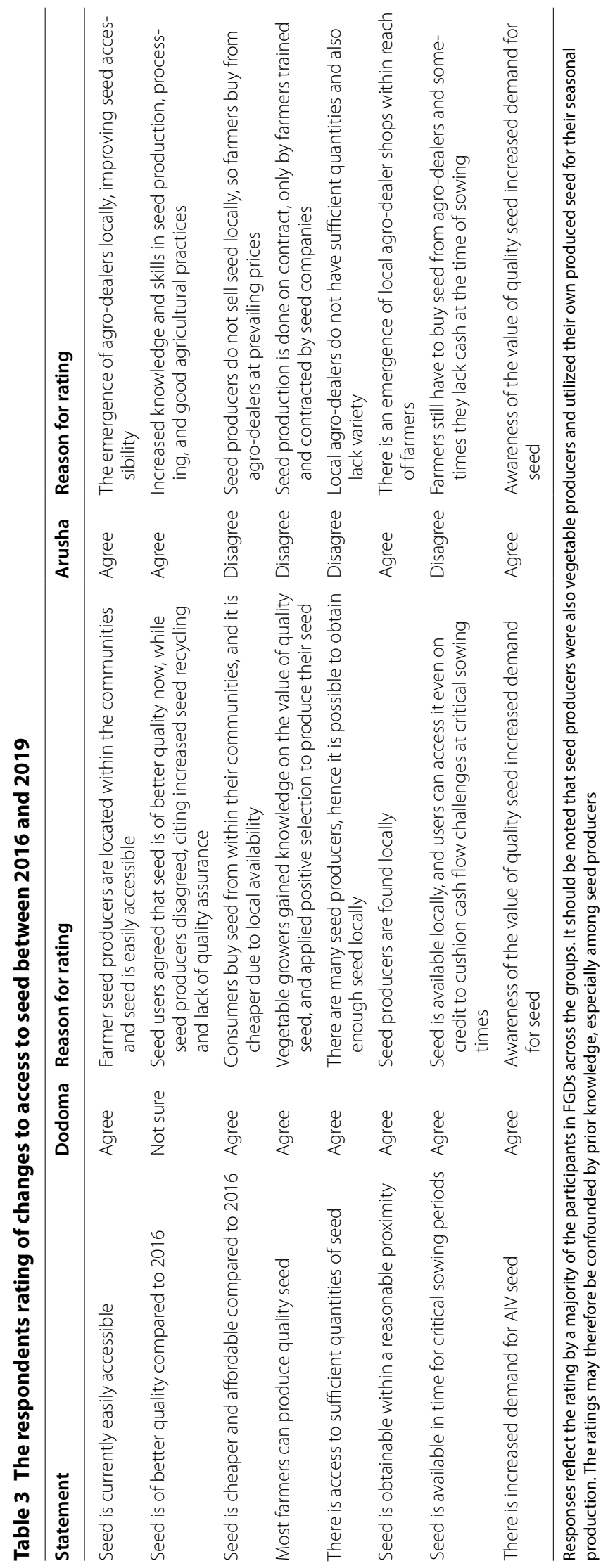


year. Besides selling seed, growers also sold AIV byproducts, such as amaranth leaves cleared during thinning of direct-seeded crops, and leftover fruits for tomato and eggplant once the ones for seed had been harvested. These provided an additional source of income and an important component of household nutritional needs. Respondents estimated that AIV seed production contributed over $50 \%$ of total household income for the majority of households. As a result, the majority of seed producers reported improvement in their household welfare and investment in other income-generating ventures.

\section{Discussion}

This study assessed the post-project sustainability factors of farmer seed production for AIVs in Tanzania. Results show that both contract and QDS farmers sustained AIV seed production, after the GSI project providing benefits for participating households and the community at large. For seed producers, seed production provided a sustainable source of income contributing over $50 \%$ of total household incomes. In comparison to traditional crops, AIV seed fetched a higher value per unit, and their early maturity provided a regular income because farmers were able to plant several crops per growing season (2-3 times a year) compared to key staples that were grown only once a year [23]. Other studies [1, 38, 43] report similar results, indicating that farmer seed enterprises for AIVs have the potential for higher incomeearning opportunities at both the farmer and community levels. Similarly, David [14] reported higher earnings by the farmer seed enterprises for common beans in Uganda compared to traditional income-earning activities such as the sale of food crops. At the community level, farmer seed production contributed to the increased availability of AIV seed for vegetable growers, particularly for farmers in the central where seed production was under QDS. Other studies have also shown that the QDS system may be appropriate in some contexts to bridge the gaps between formal and informal seed systems [13]. Farmers reported an increasing demand for quality seed attributed to increased demand for AIVs for health and nutritional benefits. Gido et al. [20] reported a positive and significant correlation between awareness of medicinal benefits associated with indigenous vegetables and consumption intensity. Also, the growing demand for AIVs in most urban areas [45], implies that farmers can grow and benefit from them.

For both seed production models, the market-oriented approach and partnership building with the formal sector provided an assured market for the seed. The success of market-based approaches in sustainable seed production and supply has been reported elsewhere
[48]. Contracted seed growers typically had guaranteed prices for their seed that were set at the beginning of the season, which motivated their continued participation in seed production. Besides, the embedded support services in the contracts, e.g. cash advances were considered essential to seed growers' participation and long-term viability of the contract arrangements as reported elsewhere [37]. However, there were issues associated with contracts, emanating principally from how they were negotiated and who was contracted. Some farmers still felt that contracts were not fair on price, product delivery, and inputs, while seed companies also pointed to breach of contract by farmers, giving rise to two-sided moral hazard and adverse selection problems [9]. Market linkages established during the project for QDS were also maintained and provided a market for most of the farmer-produced seed, besides seed sales within the community. However, the lack of differentiation between the enhanced quality traits of QDS and other farmer-produced seed/ grain led to a competition of seed on the market. There is a need for the government to rejuvenate the functioning of QDS through registration and inspection to enhance seed quality, traceability, and provide producers opportunities to tap into better and diverse markets.

Although the production of AIVs has traditionally been dominated by women $[32,45]$, the increased consumer acceptance of AIVs for food and the increasing importance of horticultural crops in augmenting cash income, has contributed to changing norms and beliefs about men and women's involvement in the production process [45]. This was also observed by this study as there was high participation of men in the AIV value chain. This tended to crowd out women, especially in the north, where seed production contracts were awarded mainly to men. Very few women farmers had seed production contracts because of limited land ownership and decision-making power on labour allocation, which were often put as requirements by seed companies. However, women farmers indicated that they provided most of the labour for seed production and processing, as part of their households or hired by farmers with contracts. Other studies have shown low women participation in contract farming arrangements; less than $10 \%$ in Kenya for fruits and vegetables [27]. Similar to this study [11] show that in Africa only $10-30 \%$ of contract farmers are women, yet women do a substantial amount of the work in contract farming arrangements: sometimes up to $70 \%$ of the labour required is supplied by women. Oduol and Mithöfer [35] also show that where the value chain is well developed and the returns are high, women dominate the production stage while men tend to own the fields, 
make decisions on sales, and control revenues. This highlights the need to support women to effectively participate in contract farming, to the same extent as their male counterparts.

\section{Conclusion}

The AIV case study confirmed that small-scale farmers can be organized and motivated to produce and sell good quality AIV seed, to fill the gap in seed supply by the formal sector, while providing economic benefits for seed producers. Enhanced accessed to quality seed at the community level enhances the livelihoods of a larger number of households, who are engaged in vegetable production. Nutritional awareness initiatives increased demand for AIVs for health/nutrition benefits, thereby acting as a pull factor for the rise in demand for quality seed. Through the market-based approach, the GSI project, built producer business capacity and established linkages to markets that remained operational even after project closure, and more seed companies and agents entered into contracts with farmers to produce and supply seed of AIVs. Linking formal and farmers' seed systems and improving the latter proved an effective strategy to improve local seed supply for AIVs and sustaining the functioning of the initiative.

There were, however, important differences between QDS growers in the central and contract farmers in the north. Farmers under contract had access to extension, seed quality assurance, and credit services provided by contracting seed companies. On the contrary, QDS producers lacked access to early generation seed, and quality assurance activities by TOSCI were no longer taking place. As such produced QDS was not registered which affected producers' access to premium markets, and potentially poses challenges in vouching for the quality of seed because opportunities for seed adulteration abound. Seed policy reforms need implementing including a rejuvenated quality assurance mechanism by TOSCI so that QDS producers can tap into better markets. Support to farmer-led seed systems will also ensure the development of a tailored and appropriate seed system that meets the ever-evolving needs of smallholder farmers. Lastly, the study revealed that the new farmers entering into seed production were mainly men especially in the north, with the fear that women would be crowded out as the AIV enterprises become profitable. Adoption of genderinclusive approaches in contract farming arrangements is paramount and can have multiple benefits, including decision-making and benefit of both men and women from such arrangements. While the study focused on AIVs, the observed sustainability factors can be applied to developing farmer capacity to produce seed of other open- or self-pollinating crops.

\begin{abstract}
Abbreviations
AIVs: African indigenous vegetables; ASA: Agricultural Seed Agency; CABI: Centre for Agriculture and Biosciences International; CIAT: International Centre for Tropical Agriculture; FGDs: Focus group discussions; GSI: Good Seed Initiative; QDS: Quality Declared Seed; TARI: Tanzania Agricultural Research Institute; TOSCI:Tanzania Official Seed Certification Institute; TZS: Tanzania Shillings; URT : United Republic of Tanzania;WHO: World Health Organization.
\end{abstract}

\section{Acknowledgements}

The study was funded by CABI Development Fund (CDF). CABI is an international intergovernmental organization and we gratefully acknowledge the core financial support from our member countries (and lead agencies) including the United Kingdom Foreign, Commonwealth, and Development Office (FDCO), China (Chinese Ministry of Agriculture), Australia (Australian Centre for International Agricultural Research), Canada (Agriculture and Agri-Food Canada), Netherlands (Directorate-General for International Cooperation-DGIS), Switzerland (Swiss Agency for Development and Cooperation) and Ireland (Irish Aid, International Fund for Agricultural Development-IFAD). See https ://www.cabi.org/about-cabi/who-we-work-with/key-donors/ for details'The GSI project was funded by Irish Aid and implemented through a partnership between CABI, the World Vegetable Center in Arusha Tanzania, Tanzania Agricultural Research Institute Tengeru (TARI-Tengeru), Inades Formation Tanzania in Dodoma, and farmer organizations. We greatly appreciate the partners for their support and contribution to this study. We appreciate contributions from seed companies in Arusha, Agro-dealers in Dodoma, Kongwa and Mpwapwa, and farmers in Arumeru, Kongwa and Mpwapwa districts. We appreciate the contribution of ASA and TOSCl as well as District Extension Department. GSI activities in Tanzania built on earlier activities with funding from the Association for Strengthening Agricultural Research in Eastern and Central Africa (ASARECA) Multi-Donor Trust Fund.

\section{Authors' contributions}

MKK (conceptualization, study design, tools preparation, data collection, analysis and manuscript preparation), MB (conceptualization, study design, tools preparation, data collection, analysis and manuscript preparation), JN (tools preparation, data collection, report review), JO (tools preparation, report review), DM (data collection), SSJ (data collection), RFK (tools review, report review), FW (conceptualization, study design, tools review, report review), DK (conceptualization, tools review, report review), JAT (study design, tools review, report review) and DR (study design, report review). All authors read and approved the final manuscript.

Funding

The study was funded by CABI Development Fund (CDF).

\section{Availability of data and materials}

Data and materials for this study are available and will be provided to the journal upon request.

\section{Ethics approval and consent to participate}

The research, methods and tools were internally approved by CABI and partner organization (World Veg, Inades Formation, and TARI). Respective District Administrations and Extension Departments were contacted, who gave consent to collect data.

\section{Consent for publication}

Research team obtained consent from respondents for interviews, data recording and anonymous publication for research purposes only. Consent was given verbally.

\section{Competing interests}

Authors declare no competing interests.

\section{Author details}

${ }^{1}$ CABI Africa, P.O. Box 633-00621, Nairobi, Kenya. ${ }^{2}$ Inades Formation, P.O. Box 203, Dodoma, Tanzania. ${ }^{3}$ World Vegetable Center, Duluti, P.O. Box 10, Arusha, Tanzania. ${ }^{4}$ Tanzania Agricultural Research Institute (TARI), Tengeru, Arusha, Tanzania. ${ }^{5}$ CIAT, Arusha, Tanzania. ${ }^{6}$ CABI Delemont, Switzerland, Switzerland. 
Received: 20 July 2020 Accepted: 28 January 2021

Published online: 28 May 2021

\section{References}

1. Afari-Sefa V, Chagomoka T, Karanja DK, Njeru E, Samali S, Katunzi A, Mtwaenzi H, Kimenye L. Private contracting versus community seed production systems: Experiences from farmer-led seed enterprise development of indigenous vegetables in Tanzania. Acta Hort 2013;1007(1):671-80.

2. Afari-Sefa V, Tenkouano A, Ojiewo C, Keatinge JDH, Hughes JA. Vegetable breeding in Africa: constraints, complexity and contributions toward achieving food and nutritional security. Food Sec. 2012;4(1):115-27.

3. Akpo E, Muricho G, Lukurugu GA, Opie H, Ojiewo CO, Varshney R. Legume seed production for sustainable seed supply and crop productivity: case of groundnut in Tanzania and Uganda. J Crop Improvement. 2020:34(4):518-39. https://doi.org/10.1080/15427528.2020.1740368.

4. Alemu D, Bishaw Z. Commercial behaviours of smallholder farmers in wheat seed use and its implication for demand assessment in Ethiopia. Develop Pract. 2015;25(6):798-814. https://doi.org/10.1080/09614 524.2015.1062469.

5. Alemu D, Mwangi W, Nigussie M, Spielman DJ. The maize seed system in Ethiopia: challenges and opportunities in drought prone areas. Afr J Agric Res. 2008;3(4):305-14

6. Almekinders CJM, Louwaars NP. The importance of the farmers'seed systems in a functional national seed sector. J New Seeds. 2002;4(12):15-33. https://doi.org/10.1300/J153v04n01_02.

7. ASARECA/KIT. Tanzania Seed Sector Assessment: A Participatory National Seed Sector Assessment for the Development of an Integrated Seed Sector Development (ISSD) Programme in Tanzania. Association for Strengthening Agricultural Research in Eastern and Central Africa (ASARECA) and Royal Tropical Institute (KIT), Entebbe, Uganda. 2014.

8. Audi P, Nagarajan L, Jones RB. Seed interventions and cultivar diversity in pigeon pea: a farmer based assessment in Eastern Kenya. J New Seeds. 2008;9(2):111-27. https://doi.org/10.1080/15228860802073016.

9. Barrett CB, Bachke ME, Bellemare MF, Michelson HC, Narayanan S, Walker TF. Smallholder participation in contract farming: comparative evidence from five countries. World Dev. 2012;40(4):715-30.

10. Blagojević L, Frede K, Klopsch R, Neugart S, Neumann A, Ngwene B, Norkeweit J, Schröter D, Schröter A, Schweigert FJ, Wiesner M, Schreiner M. Are neglected plants the food for the future? Crit Rev Plant Sci. 2016;35(2):106-19. https://doi.org/10.1080/07352689.2016.1201399.

11. Brewin S, Murphy S. The farmer and her husband: legal innovations for women in contract farming (Agriculture policy brief No.8, Feb 2019). International Institute for Sustainable Development. 2019.

12. Coomes OT, McGuire SJ, Garine E, Caillon S, McKey D, Demeulenaere E, Jarvis D, Aistara G, Barnaud A, Clouvel P, Emperaire L, Louafi S, Martin P, Massol F, Pautasso M, Violon C, Wencélius J. Farmer seed networks make a limited contribution to agriculture? Four common misconceptions. Food Policy. 2015;56:41-50

13. Croft MM, Marshall MI, Odendo M, Ndinya C, Ondego NN, Obura P, Hallett SG. Formal and informal seed systems in Kenya: supporting indigenous vegetable seed quality. J Develop Stud. 2018;54(4):758-75. https://doi. org/10.1080/00220388.2017.1308487.

14. David S. Farmer seed enterprises: A sustainable approach to seed delivery? Agric Hum Values. 2004;21(4):387-97. https://doi.org/10.1007/s1046 0-004-1247-5

15. Dinssa FF, Hanson P, Dubois T, Tenkouano A, Stoilova J, Hughes JDA, Keatinge JDH. AVRDC - the World Vegetable Center's women-oriented improvement and development strategy for traditional African vegetables in sub-Saharan Africa. Eur J Horticult Sci. 2016;81:91-105.

16. Elliot A. Registering and Certifying Agricultural Inputs in Tanzania: An Updated Assessment of Key Constraints and Recommendations for Change. Alliance for a Green Revolution in Africa (AGRA). 2016. https:// www.aecfafrica.org/sites/default/files/2017-11/AECF_Tanzania\%20Inp ut\%20Certification\%20Update\%20220117.pdf.

17. Etwire PM, Atokple IDK, Buah SSJ, Karikari AL. Analysis of the seed system in Ghana. Int J Adv Agric Res. 2013;7:13.

18. FAO \& ICRISAT. Community Seed Production. In: Workshop Proceedings, 9-11 December 2013. FAO, Rome \& ICRISAT, Addis Ababa. 2015.
19. Ghosh-Jerath S, Singh A, Magsumbol MS, Kamboj P, Goldberg G. Exploring the potential of indigenous foods to address hidden hunger: nutritive value of indigenous foods of santhal tribal community of Jharkhand, India. J Hunger Environ Nutr. 2016;11(4):548-68. https://doi. org/10.1080/19320248.2016.1157545.

20. Gido EO, Ayuya OI, Owuor G, Bokelmann W. Consumption intensity of leafy African indigenous vegetables: towards enhancing nutritional security in rural and urban dwellers in Kenya. Agric Food Econ. 2017;5(1):14. https://doi.org/10.1186/s40100-017-0082-0.

21. HODECT. Tanzania Horticultural Development Strategy 2012- 202. Horticultural Development Council of Tanzania (HODECT). 2010.

22. Kansiime KM, Mastenbroek A. Enhancing resilience of farmer seed system to climate-induced stresses: Insights from a case study in West Nile region Uganda. J Rural Stud. 2016;47(2):220-30.

23. Kansiime M, Nicodemus J, Kessy RF, Afari-sefa V, Marandu D, Samali S, Swarbrick P, Romney D, Karanja D. Good seed for quality produce: indigenous vegetables boost farmer incomes and livelihoods in Tanzania. 2016. http://www.cabi.org/Uploads/CABI/long-case-studies/Case\%20stu dy\%2017.pdf.

24. Kansiime MK, Ochieng J, Kessy R, Karanja D, Romney D, Afari-Sefa V. Changing knowledge and perceptions of African indigenous vegetables: the role of community-based nutritional outreach. Develop Pract. 2018;28(4):480-93. https://doi.org/10.1080/09614524.2018.1449814.

25. Kusena K, Wynberg R, Mujaju C. Do smallholder farmer-led seed systems have the capacity to supply good-quality, fungal-free sorghum seed? Agric Food Sec. 2017;6(52):1-12. https://doi.org/10.1186/s4006 6-017-0131-7.

26. Louwaars NP, de Boef WS. Integrated seed sector development in Africa: a conceptual framework for creating coherence between practices, programs, and policies. J Crop Improvement. 2012;26(1):39-59. https:// doi.org/10.1080/15427528.2011.611277.

27. Man-Kwun C. Improving opportunities for women in smallholder based supply chain: business case and practical guidance for international food companies. 2010.

28. McGuire S, Sperling L. The links between food security and seed security: facts and fiction that guide response. Develop Practice. 2011;21(45):493-508. https://doi.org/10.1080/09614524.2011.562485.

29. McGuire S, Sperling L. Seed systems smallholder farmers use. Food Security. 2016;8(1):179-95. https://doi.org/10.1007/s12571-015-0528-8.

30. McGuire SJ, Sperling L. Making seed systems more resilient to stress. Global Environ Change. 2013;23:644-53.

31. Muthoni J, Nyamongo DO. Seed Systems in Kenya and their relationship to on-farm conservation of food crops. J New Seeds. 2008;9(4):330-42. https://doi.org/10.1080/15228860802492273.

32. Obuobie E, Hope L. Characteristics of urban vegetable farmers and gender issues. In: Drechsel P, Keraita B, Editors. Irrigated Urban Vegetable Production in Ghana Characteristics, Benefits and Risk Mitigation. Colombo: International Water Management Institute [IWMI]. 2014. pp. 28-37

33. Ochieng J, Afari-Sefa V, Karanja D, Kessy R, Rajendran S, Samali S. How promoting consumption of traditional African vegetables affects household nutrition security in Tanzania. Renewable Agric Food Syst. 2016;1-11:9.

34. Ochieng J, Afari-Sefa V, Karanja D, Kessy R, Rajendran S, Samali S. How promoting consumption of traditional African vegetables affects household nutrition security in Tanzania. Renewable Agric Food Syst. 2018;33(2):105-15. https://doi.org/10.1017/\$1742170516000508.

35. Oduol JBA, Mithöfer D. Constraints to and opportunities for women's participation in high value agricultural commodity value chains in Kenya Promoting women's entrepreneurship: Which policies and practices work best? International Research and Policy Seminar: Maastricht School of Management, the Netherlands; 2014.

36. Okello JJ, Zhou Y, Kwikiriza N, Ogutu S, Barker I, Schulte-Geldermann E, Atieno E, Ahmed JT. Productivity and food security effects of using of certified seed potato: the case of Kenya's potato farmers. Agric Food Sec. 2017:6(1):25. https://doi.org/10.1186/s40066-017-0101-0.

37. Poku A-G, Birner R, Gupta S. Making contract farming arrangements work in Africa's bioeconomy: evidence from cassava outgrower schemes in Ghana. Sustainability. 2018;10(5):1604. https://doi.org/10.3390/su100 51604.

38. Rajendran S, Afari-Sefa V, Karanja DK, Musebe R, Romney D, Makaranga MA, Samali S, Kessy RF. Farmer-led seed enterprise initiatives to access 
certified seed for traditional African vegetables and its effect on incomes in Tanzania. Int Food Agribusiness Manag Rev. 2016;19(1):1-24.

39. Rajendran S, Afari-Sefa V, Shee A, Bocher T, Bekunda M. Does crop diversity contribute to dietary diversity? Evidence from integration of vegetables into maize-based farming systems. Agric Food Sec. 2017;6(1):50. https://doi.org/10.1186/s40066-017-0127-3.

40. Sisay DT, Verhees FJHM, van Trijp HCM. Seed producer cooperatives in the Ethiopian seed sector and their role in seed supply improvement: A review. J Crop Improvement. 2017;31(3):323-55. https://doi. org/10.1080/15427528.2017.1303800.

41. [Record \#743 is using a reference type undefined in this output style.]

42. van Etten J, Noriega I, Fadda C, Thomas E. Seed systems for crop and tree diversity in sustainable food systems. In: Mainstreaming Agrobiodiversity in Sustainable Food Systems: Scientific Foundations for an Agrobiodiversity Index - Summary. Bioversity International, Rome, Italy, 2016. p. 81-101

43. Weinberger $\mathrm{K}$, Lumpkin TA. Diversification into Horticulture and Poverty Reduction: A Research Agenda. World Develop. 2007;35(8):1464-80. https ://doi.org/10.1016/j.worlddev.2007.05.002.

44. Weinberger K, Msuya J. Indigenous Vegetables in Tanzania- Significance and Prospects $(31,04-600)$. Shanhua, Taiwan: AVRDC-The World
Vegetable Center, Technical Bulletin No. 31, AVRDC Publication 04-600. 2004.

45. Weinberger K, Pasquini M, Kasambula P, Asambuko-Onyango M. Supply chains for indigenous vegetables in urban and peri-urban areas of Uganda \& Kenya: a gendered perspective. 2011. https://www.researchga te.net/publication/252629561

46. Westengen OT, Brysting AK. Crop adaptation to climate change in the semi-arid zone in Tanzania: the role of genetic resources and seed systems. Agric Food Security. 2014;3(1):3. https://doi. org/10.1186/2048-7010-3-3.

47. Wilson RT, Lewis J. The Maize Value Chain in Tanzania: A report from the Southern Highlands Food Systems Programme. Food and Agriculture Organization of the United Nations (FAO); 2015.

48. Witcombe JR, Devkota KP, Joshi KD. Linking community-based seed producers to markets for a sustainable seed supply system. Exp Agric. 2010;46(4):425-37. https://doi.org/10.1017/S001447971000061X.

\section{Publisher's Note}

Springer Nature remains neutral with regard to jurisdictional claims in published maps and institutional affiliations.
Ready to submit your research? Choose BMC and benefit from:

- fast, convenient online submission

- thorough peer review by experienced researchers in your field

- rapid publication on acceptance

- support for research data, including large and complex data types

- gold Open Access which fosters wider collaboration and increased citations

- maximum visibility for your research: over $100 \mathrm{M}$ website views per year

At BMC, research is always in progress.

Learn more biomedcentral.com/submissions 